\title{
Manajemen Sumber Daya Manusia dalam Meningkatkan Kompetensi Guru Melaksanakan Pembelajaran Daring
}

\author{
Wilis Werdiningsih \\ IAIN Ponorogo, Indonesia \\ werdiningsih@iainponorogo.ac.id
}

DOI: https://doi.org/10.21154/ sajiem.v2i1.48

\begin{abstract}
Abstrak
Masa pandemi yang sampai saat ini masih berlangsung, menuntut guru untuk mampu melaksanakan pembelajaran secara daring. Pembelajaran daring adalah pembelajaran tanpa adanya kegiatan tatap muka, yang dilakukan menggunakan berbagai platform yang tersedia di internet. Kemampuan guru dalam memanfaatkan media teknologi yang ada, sangat berpengaruh terhadap pelaksanaan pembelajaran daring ini. Sekolah memiliki tanggung jawab melaksanakan manajemen sumber daya manusia (SDM) dengan baik sebagai upaya memastikan seluruh guru dapat melaksanakan pembelajaran daring menggunakan berbagai platform yang tersedia. Penelitian ini bertujuan untuk mengkaji lebih mendalam berkaitan dengan manajemen SDM dalam peningkatan kemampuan guru dalam melaksanakan pembelajaran daring. Metode library research digunakan melalui penggalian informasi dari berbagai literatur terkait dengan pelaksanakaan manajemen SDM di lembaga pendidikan serta upaya peningkatan kompetensi guru dalam melaksanakan pembelajaran daring. Hasil menunjukkan bahwa peningkatan kompetensi guru dalam melaksanakan pembelajaran daring dapat dilakukan melalui pelaksanaan kegiatan pelatihan pembelajaran daring, pembentukan tim khusus yang fokus membantu guru dalam melaksanakan pembelajaran daring, serta kegiatan supervisi yang berkelanjutan.
\end{abstract}

Kata Kunci: manajemen SDM, kompetensi guru, pembelajaran daring.

\section{Pendahuluan}

Lembaga pendidikan merupakan tempat di mana peserta didik menghabiskan waktunya untuk belajar berbagai ilmu pengetahuan. Berbagai ilmu tersebut diterima melalui kegiatan pembelajaran yang dilaksanakan oleh guru. Dalam UU Sisdiknas nomor 20 tahun 2003 dijelaskan bahwa pembelajaran adalah proses interaksi peserta didik dengan pendidik dan sumber belajar pada suatu lingkungan belajar. Dari pengertian tersebut dapat dipahami 
bahwa dalam kegiatan pembelajaran yang sebenarnya terdapat interaksi antara peserta didik dan pendidik. Interaksi ini dipahami sebagai sebuah interaksi yang terjadi secara langsung. Artinya pendidik dan peserta didik bertemu secara langsung di satu ruangan, di mana pendidik berupaya untuk menyampaikan materi, dan peserta didik berupaya untuk memahami apa yang disampaikan oleh guru. Sehingga melalui serangkaian kegiatan yang dilaksanakan dalam kegiatan pembelajaran tersebut, tujuan dari pembelajaran yakni meningkatnya kemampuan kognitif, psikomotorik dan afektif peserta didik dapat tercapai.

Hal yang berbeda terjadi pada masa pandemi. Interaksi secara langsung dalam kegiatan pembelajaran sebagaimana mestinya tidak dapat dilaksanakan. Wabah covid 19 menghantui seluruh warga dunia termasuk Indonesia. Oleh sebab itu pemerintah membuat serangkaian kebijakan dengan harapan dapat menekan laju penambahan pasien positif covid. Salah satunya adalah kebijakan di bidang pendidikan yakni dengan dilaksanakan pembelajaran jarak jauh (PJJ). Bentuk dari PJJ adalah pembelajaran daring atau juga disebut dengan pembelajaran online. Pembelajaran daring atau online didefinisikan sebagai pengalaman transfer pengetahuan menggunakan video, audio, gambar, komunikasi teks, perangkat lunak dan dengan dukungan jaringan internet. ${ }^{1}$ Pembelajaran online dapat memanfaatkan platform berupa aplikasi, website, jejaring sosial maupun learning management system. Infrastruktur yang mendukung pembelajaran online gratis melalui berbagai ruang diskusi seperti google classroom dan whatsapp. Sedangkan video teleconference dapat memanfaatkan zoom, google meet ataupun jitsi meet. Seluruh platform tersebut dapat dimanfaatkan sesuai dengan kebutuhan guru maupun peserta didik.

Selain tidak adanya interaksi secara langsung antara pendidik dengan peserta didik, pembelajaran daring yang dilaksanakan peserta didik di rumah masing-masing, menuntut partisipasi aktif dari orang tua. Jika sebelumnya orang tua hanya berperan dalam mendampingi anak ketika mengerjakan tugas di rumah lantaran anak belajar di sekolah, maka dalam pembelajaran daring orang tua mengambil alih peran guru dalam mendampingi belajar sekaligus mengerjakan tugas. Sehingga dalam pembelajaran daring ini peran orang tua lebih besar dibandingkan dengan sebelum daring. Bentuk peran orang tua sebenarnya adalah bentuk peran guru di sekolah. Peran orang tua adalah menjadi orang tua yang memotivasi dalam segala hal. Dalam hal ini peran orang tua adalah membimbing dan memberikan motivasi kepada anak agar anak tetap bersemangat dalam melakukan kegiatan di rumah. ${ }^{2}$

Sebelum adanya pandemi, para guru seringkali disibukkan dengan berbagai pelatihan penyusunan perangkat pembelajaran, pembuatan, media, penerapan strategi pembelajaran hingga melaksanakan penilaian di kelas. Namun saat ini guru dituntut untuk lebih fokus dalam mengadakan inovasi kegiatan pembelajaran. Sebab kegiatan pembelajaran semenjak bulan Maret tahun 2020 lalu yang dilaksanakan secara daring menuntut guru untuk mampu memanfaatkan teknologi informasi.

Pembelajaran daring menuntut guru terampil dalam melaksanakan kegiatan pembelajaran melalui berbagai platform yang ada di internet. Jika sebelumnya guru sudah mengenal berbagai platform tersebut, tentu hal ini bukan merupakan hal yang sulit. Namun jika sebelumnya guru belum pernah mengenal sama sekali, karena fokus pada pembelajaran secara langsung, maka tentu guru akan merasa sulit untuk melaksanakan pembelajaran daring ini. Dengan demikian kepala sekolah sebagai penanggung jawab kegiatan di lembaga pendidikan harus memastikan seluruh guru di sekolahnya mampu melaksanakan pembelajaran daring. Manajemen sumber daya manusia menjadi hal yang harus diperhatikan sebagai upaya menjamin guru mampu melakukan perannya sebagai pendidik yang baik di

\footnotetext{
${ }^{1}$ Luh Devi Herliandry et al., "Pembelajaran Pada Masa Pandemi Covid-19," Jurnal Teknologi Pendidikan Volume 22 Nomor 1 (April 2020): 67.

${ }^{2}$ Agustien Lilawati, "Peran Orang Tua Dalam Mendukung Kegiatan Pembelajaran Di Rumah Pada Masa Pandemi," Jurnal Obsesi: Jurnal Pendidikan Anak Usia Dini Volume 5 nomor (2021): 
tengah masa pandemi yang hingga saat ini masih berlangsung. Penelitian ini berupaya untuk menggali secara lebih mendalam berkaitan dengan pelaksanaan manajemen sumber daya manusia dalam meningkatkan kompetensi guru melaksanakan pembelajaran daring.

\section{Temuan dan Pembahasan}

\section{Manajemen Sumber Daya Manusia}

Pelaksanaan manajemen pada hakikatnya adalah terletak pada manajemen sumber daya manusia (SDM) atau dapat dikatakan bahwa manajemen SDM identik dengan manajemen itu sendiri. ${ }^{3}$ Manajemen SDM merupakan bagian dari ilmu manajemen yang memfokuskan perhatiannya pada pengaturan peranan sumber daya manusia dalam kegiatan suatu organisasi. ${ }^{4}$ Melalui manajemen SDM diharapkan terjadi peningkatan kinerja karyawan di suatu lembaga. Jika mengacu pada lembaga pendidikan, maka karyawan yang dimaksud adalah pendidik dan tenaga kependidikan. Dalam bukunya, Mulyasa menyebutkan bahwa tujuan dari manajemen SDM adalah mendayagunakan tenaga kependidikan (guru dan karyawan) secara efektif dan efisien untuk mencapai hasil yang optimal namun tetap dalam kondisi yang menyenangkan. ${ }^{5}$ Sehingga seorang kepala sekolah bertugas tidak hanya mengusahakan tercapainya tujuan sekolah, tetapi juga tujuan tenaga kependidikan secara pribadi. $^{6}$

Manusia merupakan faktor strategis dalam semua kegiatan institusi/organisasi. SDM ini merupakan faktor terpenting di antara faktor-faktor lain yang ada yang turut menentukan pencapaian tujuan organisasi. ${ }^{7}$ Sadili Samsudin memaparkan bahwa dalam lembaga pendidikan Islam, aset paling penting yang harus dimiliki dan harus diperhatikan dalam manajemen adalah manusia. Manusia yang merancang dan menghasilkan inovasi pendidikan, mengawasi mutu, memasarkan produk, mengalokasikan sumber daya finansial, serta merumuskan seluruh strategi dan tujuan organisasi. Sumber daya manusia inilah yang membuat sumber daya lainnya dapat berjalan. ${ }^{8}$ Oleh sebab itu pelaksanaan manajemen SDM perlu mendapatkan perhatian khusus dari pimpinan.

Di dalam kegiatan manajemen SDM terdapat serangkaian tahapan yang harus dilaksanakan. Yakni mulai dari perencanaan SDM, rekrutmen, seleksi, penempatan, penampilan dan penilaian kinerja, pelatihan dan pengembangan, kompensasi keselamatan kerja, pengembangan karir, dan pensiun atau jaminan hari tua. Seluruh rangkaian kegiatan tersebut dilaksanakan untuk menjamin kinerja karyawan agar maksimal serta kesejahteraannya dapat tercapai.

Perencanaan merupakan fungsi yang paling awal dari keseluruhan fungsi manajemen. Perencanaan adalah proses kegiatan yang menyiapkan secara sistematis kegiatan-kegiatan yang akan dilakukan untuk mencapai tujuan. ${ }^{9}$ Perencanaan SDM dilakukan melalui identifikasi kebutuhan SDM di lembaga pendidikan. Dengan adanya perencanaan yang baik, kegiatan seleksi, pelatihan dan pengembangan, serta kegiatan lainnya yang berkaitan dengan SDM lebih terarah. Di antara manfaat perencanaan ini adalah organisasi dapat memanfaatkan SDM yang ada dalam organisasi dengan lebih baik, produktivitas kerja dari tenaga yang sudah

\footnotetext{
${ }^{3}$ Tjuju Yuniarsih and Suwatni, "Manajemen Sumber Daya Manusia (Teori, Aplikasi Dan Isu Penelitian” (Bandung: Alfabeta, 2013), 1.

${ }^{4}$ Yuniarsih and Suwatni, 1.

${ }^{5}$ Mulyasa, "Manajemen Berbasis Sekolah (Konsep, Strategi Dan Implementasi)" (Bandung: PT Remaja Rosdakarya, 2014), 42.

${ }^{6}$ Mulyasa, 45 .

${ }^{7}$ Hidayatus Sholihah, "Implementasi Manajemen SDM Di MAN Yogyakarta III," Al Fikr: Jurnal Studi Dan Penelitian Pendidikan Islam Volume 1 Nomor 1 (February 2018): 59.

${ }^{8}$ Sadili Samsudin, Manajemen Sumber Daya Manusia (Bandung: Pustaka Setia, 2006), 21.

${ }^{9}$ Imam Machali dan Ara Hidayat, The Handbook Of Education Management (Jakarta:

Prenadamedia Group, 2016), 19.
} 
ada dapat ditingkatkan serta perencanaan SDM ini berkaitan dengan penentuan kebutuhan akan tenaga kerja di masa yang akan datang, baik dari segi jumlah maupun kualifikasinya. Dengan demikian kebutuhan SDM di suatu lembaga benar-benar terencana dengan baik sehingga mendukung seluruh program yang ada di lembaga tersebut.

Rekrutmen, seleksi dan penempatan merupakan serangkaian kegiatan pengadaan tenaga yang sesuai dengan kebutuhan. Rekrutmen dapat dilaksanakan dengan memanfaatkan sumber internal maupun sumber eksternal. ${ }^{10}$ Sumber internal meliputi karyawan yang ada saat ini yang dapat dicalonkan untuk dipromosikan, dipindahtugaskan atau dirotasi tugasnya atau mantan karyawan yang dapat dipanggil kembali. Sementara sumber eksternal adalah rekrutmen yang dilakukan dengan memasang pengumuman di berbagai media, sehingga siapa saja yang memenuhi kualifikasi dapat melamar pekerjaan tersebut. Melalui rekrutmen dengan memanfaatkan sumber eksternal ini dapat menghasilkan calon pekerja yang banyak dan berbobot sesuai dengan kebutuhan lembaga. Setelah melalui tahapan rekrutmen, maka selanjutnya adalah tahapan seleksi. Di antara hal yang harus diperhatikan dalam seleksi adalah analisis pekerjaan yang akan dipercayakan kepada pelamar, persyaratan yang harus dipenuhi serta prestasi pelamar. Setelah melalui proses seleksi dan dinyatakan diterima, maka tahapan selanjutnya adalah penempatan atau placement. Penempatan adalah suatu proses kegiatan yang dilakukan oleh pimpinan untuk menentukan posisi jabatan, lokasi kerja sehingga karyawan dapat melakukan tugasnya di dalam organisasi. Dalam penempatan ini perlu diperhatikan kesesuaian antara posisi dan kompetensi yang dimiliki (the right man on the right place).

Setelah dinyatakan diterima dan ditempatkan, maka kegiatan selanjutnya adalah penampilan dan penilaian kinerja. Penampilan merupakan hasil kerja dari seorang karyawan yang bersifat konkret yang dapat diamati dan diukur. Diharapkan dengan penempatan jabatan yang sesuai dengan kompetensi, maka pendidik maupun peserta didik dapat bekerja dengan maksimal. Sementara itu, kegiatan penilaian merupakan kegiatan penting dilakukan oleh seorang pimpinan. Hal ini untuk memastikan seluruh orang-orang yang bekerja di lembaga bekerja sesuai dengan tupoksinya masing-masing. Di dalam lembaga pendidikan, penilaian dilakukan melalui kegiatan supervisi akademik maupun supervisi manajerial yang dilakukan oleh kepala sekolah dan juga pengawas.

Kegiatan selanjutnya adalah pelatihan dan pengembangan. Seorang kepala sekolah perlu memikirkan bagaimana agar karyawannya memiliki kesempatan untuk meningkatkan kompetensinya. Hal ini mengingat program peningkatan kualitas SDM melalui pendidikan akan memberi manfaat pada lembaga berupa produktifitas, moral, efisiensi kerja, stabilitas, serta fleksibilitas lembaga. ${ }^{11}$ Berbagai program pelatihan yang dilaksanakan bertujuan untuk memperbaiki penguasaan berbagai keterampilan dan teknik pelaksanaan kerja tertentu untuk kebutuhan sekarang. Sedangkan pengembangan dilakukan sebagai upaya untuk menyiapkan karyawan yang siap memangku jabatan tertentu di masa yang akan datang. Pendidikan dan pelatihan akan menjawab problematika kelemahan SDM di lembaga pendidikan, di mana seluruh SDM harus tumbuh dan berkembang, mampu bersaing secara kompetitif dengan perkembangan zaman yang bergerak maju, sehingga pada akhirnya lahirlah SDM lembaga pendidikan dengan mutu terbaik dan melahirkan output yang terbaik pula. ${ }^{12}$

Kompensasi merupakan balas jasa yang diberikan organisasi kepada pegawai yang dapat dinilai dengan uang dan mempunyai kecenderungan diberikan secara tetap. ${ }^{13}$ Kompensasi yang maksimal akan mempengaruhi derajat kepuasan guru dalam melaksanakan

\footnotetext{
${ }^{10}$ Kompri, Manajemen Pendidikan 2 (Bandung: Alfabeta, 2014), 94-95.

${ }^{11}$ Kompri, 110.

${ }^{12}$ Dhoni Kurniawati, "Manajemen Sumber Daya Manusia Dalam Perspektif Islam Dan Relevansinya Dengan Manajemen Modern," Ijtimaiyya: Jurnal Pengembangan Masyarakat Islam Volume 11 Nomor 1 (Pebruari 2018): 33.

${ }^{13}$ Mulyasa, "Manajemen Berbasis Sekolah (Konsep, Strategi Dan Implementasi)," 45.
} 
tugas dan tanggung jawabnya. Derajat kepuasan yang semakin tinggi akan semakin meningkatkan motivasi guru dalam bekerja. ${ }^{14}$ Asas dalam pemberian kompensasi adalah adil, layak dan wajar. Adil memiliki makna besaran kompensasi harus disesuaikan dengan prestasi kerja, jenis pekerjaan, resiko, tanggung jawab, jabatan dan memenuhi persyaratan internal konsistensi. Sementara asas layak dan wajar artinya kompensasi yang diterima karyawan dapat memenuhi kebutuhannya tingkat normatif yang ideal. ${ }^{15}$

Sementara itu jaminan keselamatan kerja merupakan salah satu bentuk tanggung jawab sebuah organisasi baik yang bersifat moril maupun fisik. Sedangkan tujuan promosi dalam pengembangan karier adalah untuk memberikan pengakuan, jabatan dan imbalan yang semakin besar kepada karyawan yang berprestasi kerja tinggi. Kejelasan dalam pengembangan karir ini memotivasi pendidik maupun tenaga kependidikan untuk menunjukkan prestasinya. Dan terakhir perhatian lembaga terhadap masa pensiun merupakan bentuk tanggung jawab lembaga dalam memikirkan masa depan karyawan setelah waktu masa mengabdi telah usai. Bagi lembaga swasta maka hal ini perlu diperhatikan sejak dini. Berbagai kebijakan dapat dilakukan untuk memberikan jaminan hari tua kepada seluruh pendidik maupun tenaga kependidikan yang sudah mengabdikan dirinya dalam jangka waktu yang lama kepada lembaga.

\section{Kompetensi Guru}

Guru merupakan ujung tombak kegiatan pembelajaran di kelas. Guru merupakan penentu keberhasilan dari diberlakukannya suatu kurikulum oleh pemerintah. Guru mempunyai peran yang penting dalam pendidikan, sehingga hampir semua usaha pembaharuan di bidang pendidikan bergantung pada guru. ${ }^{16}$ Di pundak guru, generasi penerus bangsa dididik untuk menjadi orang-orang yang berkompetensi yang pada akhirnya mereka akan menjadi penentu kemajuan bangsa di masa yang akan datang.

Berkaitan dengan hal tersebut, maka pemerintah memberikan perhatian yang besar terhadap guru. Berbagai kebijakan diberlakukan untuk memastikan kesejahteraan guru. Hal ini diharapkan menjadi semangat baru bagi para guru untuk mau dan mampu melakukan yang terbaik bagi generasi penerus bangsa. Selain itu, pemerintah juga menerapkan standar kompetensi bagi guru sebagai upaya menjamin bahwa guru-guru yang ada di Indonesia adalah guru-guru yang berkompetensi.

Berdasarkan undang-undang nomor 14 tahun 2005 tentang Guru dan Dosen, disebutkan bahwa guru harus memiliki empat kompetensi, yakni kompetensi pedagogiek, kepribadian, sosial dan profesional. Keempat kompetensi tersebut wajib dimiliki guru, agar guru dapat menjalankan tugas sebagai pendidik dengan baik.

Kompetensi pedagogik merupakan kompetensi yang secara khas mencirikan dan membedakan profesi guru dengan profesi lainnya. Kompetensi ini merupakan penguasaan terhadap teori perkembangan dan teori belajar. ${ }^{17}$ Berdasarkan peraturan pemerintah nomor 16 tahun 2007 , tentang standar kualifikasi dan kompetensi guru dijelaskan kompetensi pedagogik mencakup:

\footnotetext{
${ }^{14}$ Lutfi Erwin Lubis, "Lutfi Erwin Lubis, Efek Kompensasi Terhadap Motivasi Kerja Guru Pada Sekolah Widya Batam," Jurnal Dimensi Volume 7 Nomor 3 (2018): 594.

${ }^{15}$ Puput Maretha Sari, Supardi A. Bakri, and Yuliansyah M. Diah, "Pengaruh Kompensasi Terhadap Disiplin Kerja Pegawai Pada Lembaga Penjaminan Mutu Pendidikan Sumatera Selatan," Jembatan: Jurnal Ilmiah Manajemen Bisnis Dan Terapan Volume 12 Nomor 2 (Oktober 2015): 91.

${ }^{16}$ Yusutria, "Profesionalisme Guru Dalam Meningkatkan Kualitas Sumber Daya Manusia," Jurnal Curricula Volume 2 Nomor 1 (2017): 40.

${ }^{17}$ Anifa Alfia Nur, "Anifa Alfia Nur, Meningkatkan Kompetensi Pedagogik Guru Di SD Yayasan Mutiara Gambut, ," Jurnal Administrasi Pendidikan Volume 2 Nomor 1 (June 2014): 66.
} 
1. Penguasaan karakteristik peserta didik dari aspek fisik, moral, sosial, kultural, emosional dan intelektual.

2. Menguasai teori belajar dan prinsip-prinsip pembelajaran yang mendidik.

3. Mengembangkan kurikulum yang terkait dengan bidang yang diampu.

4. Menyelenggarakan kegiatan pengembangan yang mendidik.

5. Memanfaatkan teknologi infrmasi dan komunikasi untuk kepentingan penyelenggaraan kegiatan pengembangan yang mendidik.

6. Memfasilitasi pengembangan potensi peserta didik untuk mengaktualisasikan berbagai potensi yang dimiliki.

7. Berkomunikasi secara efektif, empatik dan santun dengan peserta didik.

8. Menyelenggarakan penilaian dan evaluasi proses dan hasil belajar.

9. Memanfaatkan hasil penilaian dan evaluasi untuk kepentingna pembelajaran.

10. Melakukan tindakan reflektif untuk peningkatan kualitas pembelajaran.

Selain kompetensi pedagogik, guru harus memiliki kompetensi kepribadian. Kompetensi kepribadian adalah kemampuan seorang guru dalam memiliki sifat-sifat pribadi seperti kasih sayang kepada didik, lemah lembut, rendah hati, menghormati ilmu, adil, menyenangi ijtihad, konsekuen perkataan dengan perbuatan dan sederhana. ${ }^{18}$ Berkaitan dengan kompetensi ini, berdasarkan PP nomor 16 tahun 2007 seorang guru harus menunjukkan sikap sebagai berikut:

1. Bertindak sesuai dengan norma agama, hukum, sosial dan kebudayaan nasional Indonesia.

2. Menampilkan diri sebagai pribadi yang jujur, berakhlak mulia, dan teladan bagi peserta didik dan masyarakat.

3. Menampilkan diri sebagai pribadi yang mantab, stabil, dewasa, arif dna berwibawa.

4. Menunjukkan etos kerja, tanggung jawab yang tinggi, rasa bangga menjadi guru dan rasa percaya diri.

5. Menjunjung tinggi kode etik profesi guru.

Selanjutnya guru wajib memiliki kompetensi sosial. Kompetensi sosial berkaitan dengan kemampuan guru dalam berhubungan dengan orang lain. Secara terperinci dalam PP nomor 16 tahun 2007, kompetensi ini dijelaskan sebagai berikut:

1. Bersikap inklusif, bertindak objektif, serta tidak diskriminatif karena pertimbangan kenis kelamin, agama, ras, kondisi fisik, latar belakang keluarga dan status sosial ekonomi.

2. Berkomunikasi secara efektif, empatik, dan santun dengan sesama pendidik, tenaga kependidikan, orang tua dan masyarakat.

3. Beradaptasi di tempat bertugas di seluruh wilayah Indonesia yang memiliki keragaman sosial budaya.

4. Berkomunikasi dengan komunitas profesi sendiri dan profesi lain secara lisan dan tulisan atau bentuk lain.

Terakhir guru wajib memiliki kompetensi profesional. Seorang guru yang profesional harus menguasai betul tentang seluk beluk pendidikan dan pengajaran serta ilmu-ilmu lain yang mendukung kompetensinya. ${ }^{19}$ Kompetensi ini mencakup:

1. Menguasai materi, struktur, konsep dan pola pikr keilmuan yang mendukung mata pelajaran yang diampu.

2. Menguasai standar kompetensi dan kompetensi dasar mata pelajaran/bidang pengembangan yang diampu.

\footnotetext{
${ }^{18}$ Ahmad Tafsir, Ilmu Pendidikan Islami (Bandung: PT Remaja Rosdakarya, 2012), 134.

${ }^{19}$ Yusutria, "Profesionalisme Guru Dalam Meningkatkan Kualitas Sumber Daya Manusia," 41.
} 
3. Mengembangkan materi pembelajaran yang diampu secara kreatif.

4. Mengembangkan keprofesionalan secara berkelanjutan dengan melakukan tindakan reflektif.

5. Memanfaatkan teknologi informasi dan komunikasi untuk berkomunikasi dan mengembangkan diri.

\section{Pelatihan Pelaksanaan Pembelajaran Daring}

Pembelajaran daring merupakan model pembelajaran yang sebelum adanya pandemi tidak terlalu dikenal. Dalam model pembelajaran ini, guru dan peserta didik tidak bertemu secara langsung melainkan melalui berbagai platform yang tersedia di internet. Pembelajaran secara daring merupakan kebijakan dari pemerintah sebagai upaya menekan laju penambahan angka covid 19. Dengan harapan tidak terjadi penambahan pasien utamanya dari bidang pendidikan.

Adanya pembelajaran daring memunculkan dilema tersendiri. Di satu sisi bagi guru yang notabene masih berusia muda, yang terbiasa memanfaatkan TI maka hal ini bukan menjadi masalah. Namun bagi sebagian guru yang berusia lanjut, yang jarang memanfaatkan TI di dalam kehidupan sehari-hari, maka hal ini tentu menimbulkan kegalauan tersendiri. Berkaitan dengan hal tersebut, maka seorang kepala sekolah perlu memberikan perhatian khusus melalui serangkaian kebijakan sebagai upaya memastikan semua guru dapat melaksanakan pembelajaran daring secara efektif.

Di dalam tahapan manajemen SDM, terdapat kegiatan pelatihan dan pengembangan. Dua kegiatan ini fokus pada pengembangan kompetensi dari guru maupun karyawan. Pengembangan SDM adalah program yang khusus dirancang oleh suatu organisasi dengan tujuan membantu karyawan dalam meningkatkan kemampuan, pengetahuan dan sikapnya. ${ }^{20}$ Sehingga kemampuan guru di dalam melaksanakan pembelajaran daring dengan memanfaatkan berbagai platform seperti google meet, google classroom dan e learning merupakan bagian dari pelatihan dan pengembangan kompetensi guru.

Salah satu upaya yang dapat dilakukan oleh kepala sekolah adalah dengan mengadakan pelatihan pelaksanaan pembelajaran daring. Pelatihan ini bisa diadakan secara mandiri oleh sekolah maupun mengikutsertakan guru di berbagai pelatihan yang diadakan oleh dinas pendidikan setempat maupun oleh lembaga swasta yang ada. Jika sekolah mengadakan secara mandiri, maka sebagai tutor bisa dari sumber internal maupun eksternal. Sumber internal dapat diperoleh dengan menunjuk salah seorang guru yang mampu di bidang TI dan memahami bagaimana pembelajaran menggunakan berbagai platform yang ada. Sementara jika hal tersebut tidak memungkinkan, maka sekolah dapat mencari tutor dari sumber eksternal.

Pelatihan ini idealnya diadakan secara berkelanjutan. Hal ini mengingat pembelajaran daring berlangsung dalam kurun waktu yang lama. Sehingga diperlukan berbagai inovasi pembelajaran daring agar peserta didik tidak merasa bosan dalam mengikutinya. Lantaran pembelajaran daring merupakan hal yang baru, maka muncul berbagai permasalahan di lapangan. Di antara beberapa permasalahan yang muncul, jika ditinjau dari aspek pendidik adalah sebagai berikut: ${ }^{21}$

1. Konten materi yang disampaikan secara daring belum tentu bisa dipahami semua peserta didik, sebab konten ini disajikan dalam bentuk e book, power point maupun video

\footnotetext{
${ }^{20}$ M. Nazar Almasri, "Manajemen Sumber Daya Manusia: Implementasi Dalam Pendidikan Islam," Kutubkhanan: Jurnal Penelitian Sosial Keagamaan Volume 19 Nomor 2 (July 2016): 142. ${ }^{21}$ Asmuni, "Asmuni, Problematika Pembelajaran Daring Di Masa Pandemi Covid-19 Dan Solusi Pemecahannya," Jurnal Paedagogy: Jurnal Penelitian Dan Pengembangan Pendidikan Volume 7 Nomor 4 (Oktober 2020): 283-84.
} 
pembelajaran. Mungkin materi dapat dipahami, tetapi pemahaman peserta didik tidak komprehensif.

2. Kemampuan guru terbatas dalam menggunakan teknologi pada pembelajaran daring.

3. Keterbatasan guru dalam mengadakan kontrol saat berlangsungnya pembelajaran daring. berikut: ${ }^{22}$

Sementara itu, permasalahan yang muncul dari aspek peserta didik adalah sebagai

1. Peserta didik kurang aktif dan tertarik dalam mengikuti pembelajaran daring meskipun mereka didukung dengan fasilitas yang memadai.

2. Peserta didik tidak memiliki perangkat handphone/gadget yang digunakan sebagai media belajar daring, jika ada itu milik orang tua mereka.

3. Sejumlah peserta didik tinggal di wilayah yang tidak memiliki akses internet.

4. Mengingat perjalanan belajar dari rumah (BDR) sudah berlangsung sekitar enam bulan sejak pertengahan Maret, menurut beberapa peserta didik terlalu lama BDR membuat mereka malas.

Sebagai upaya mengatasi hal tersebut, maka hal yang bisa dilakukan adalah:

1. Guru berupaya menyiapkan materi semenarik mungkin. Materi dapat berupa power point maupun video pembelajaran yang diunggah di youtube atau google drive. Materi yang menarik dan berganti-ganti bentuk dapat mengindarkan peserta didik dari kejenuhan.

2. Guru dapat memanfaatkan media yang paling sederhana semisal grup whatsapp. Namun guru tetap harus berupaya untuk mempelajari TI sehingga kompetensinya meningkat. Hal ini dapat dilakukan dengan mengikuti pelatihan/workshop dan juga menyimak berbagai tutorial di youtube.

3. Sebagai upaya memotivasi peserta didik, maka guru seyogyanya secara rutin melaksanakan video call. Melalui video call menjadi merasa lebih dipantau oleh guru.

Berdasarkan pemaparan di atas maka dapat disimpulkan bahwa kemampuan guru menggunakan TI di masa pandemi sangat penting. Pembelajaran daring yang sampai saat ini masih berlangsung menuntut guru untuk melakukan inovasi agar peserta didik tidak merasa jenuh di setiap kegiatan pembelajaran. Pelatihan dapat dilaksanakan secara bertahap. Mulai dari bagaimana memulai membuat kelas di google classroom atau di e learning, memberi tugas, mengisi daftar hadir, penilaian melalui tes, hingga pelatihan pembuatan video pembelajaran yang menarik.

\section{Tim Pendamping Guru dalam Melaksanakan Pembelajaran Daring}

Sebagai upaya tindak lanjut pelaksanaan pelatihan sehingga guru benar-benar menguasai materi, maka penting adanya tim pendamping khusus pelaksanaan pembelajaran daring. Tim ini bertugas untuk mendampingi seluruh guru dan sebagai tempat bertanya ketika guru mengalami berbagai kendala. Tim ini juga bertugas memantau para guru dalam melaksanakan pembelajaran daring. Sehingga tidak seorang gurupun yang tidak bisa mengajar dengan baik pada pembelajaran daring ini. Ketika guru mengalami kesulitan, maka seketika dapat bertanya kepada anggota tim.

Idealnya tim pendamping ini mendapat SK khusus dari kepala sekolah. Hal ini akan mendorong kerja tim lebih maksimal. Selain itu juga perlu dipertimbangkan jumlah tim pendamping dengan jumlah guru yang ada di sekolah. Sehingga kerja tim dapat bekerja optimal.

Berdasarkan hasil penelitian yang dilakukan Ahmad, terbukti dengan adanya pendampingan skor kompetensi guru meningkat. Awalnya sebelum dilakukan tindakan

\footnotetext{
${ }^{22}$ Asmuni, 284-85.
} 
pendampingan, rata-rata kompetensi guru dalam mengelola pembelajaran daring berada antara 60-70. Pada siklus 1 diperoleh skor kompetensi guru meningkat menjadi 65-74. Pada siklus 2 skor kompetensi guru menjadi 71-77, dan pada siklus 3 skor kompetensi guru meningkat menjadi 81-87. ${ }^{23}$ Dari penelitian tersebut dapat diketahui bahwa keberadaan tim pendamping memberikan dampak yang signifikan terhadap peningkatan kompetensi guru. Treatment yang dilakukan pendamping dalam rangka memperbaiki kompetensi guru yaitu dengan memberi bimbingan secara langsung sebelum melakukan siklus, dengan melihat rambu-rambu dalam pengelolaan PJJ-BDR. $^{24}$ Sehingga dapat disimpulkan bahwa untuk memperbaiki ataupun meningkatkan keahlian dan kompetensi guru dapat dilakukan dengan kegiatan yang bersifat menstimulasi, mengkoordinasi dan membimbing secara berkesinambungan. Layanan bimbingan dalam pendampingan mampu menjadi pijakan bagi guru untuk perbaikan berkelanjutan. ${ }^{25}$

\section{Supervisi Akademik Kepala Sekolah}

Supervisi merupakan kegiatan pembinaan yang dilakukan oleh kepala sekolah kepada para guru sehingga guru dapat melaksanakan kegiatan pembelajaran secara efektif. Supervisi akademik adalah supervisi yang menitikberatkan pengamatan pada masalah akademik, yaitu yang langsung berkaitan dengan kegiatan pembelajaran. ${ }^{26}$ Supervisi ini idealnya dilaksanakan secara berkelanjutan sehingga setiap kekurangan atau kendala yang dialami oleh guru yang berkaitan dengan kegiatan pembelajaran dapat terpantau dengan baik. Termasuk di dalamnya pada pelaksanaan pembelajaran daring.

Terdapat beberapa teknik pelaksanaan supervisi, yakni supervisi individu dan supervisi kelompok. Supervisi individu dilaksanakan dengan tatap muka secara langsung antara supervisor dengan supervise. Sementara supervisi kelompok adalah supervisi yang dilaksanakan secara bersama-sama dalam sebuah kegiatan misalnya seminar, meeting, diskusi kelompok, workshop maupun in service training. Seorang supervisor dapat menentukan teknik supervisi mana yang lebih efektif untuk diterapkan di lembaganya.

Sebagaimana telah dipaparkan sebelumnya bahwa pembelajaran daring menuntut penguasaan TI. Sehingga muncul berbagai permasalahan utamanya bagi para guru yang berusia 40 tahun ke atas. Berdasarkan penelitian yang dilakukan oleh Sarjono ditemukan beberapa kendala pembelajaran daring yakni sebagian besar guru yang berusia 40 tahun ke atas, banyak yang mengalami kesulitan dalam menggunakan teknologi digital untuk pembelajaran, kurangnya pengetahuan tentang learning management system serta kurang terbangun interaksi dua arah antara guru dengan siswa maupun guru dengan wali siswa saat pembelajaran daring. ${ }^{27}$ Oleh sebab itu supervisi akademik penting untuk dilaksanakan secara rutin, dengan harapan mendorong para guru untuk lebih bersemangat dalam menyusun perencanaan pembelajaran, mempersiapkan materi serta melaksanakan pembelajaran daring dengan baik.

Supervisi akademik dapat difokuskan pada lima aspek yang dinilai Kemendikbud saat satuan pendidikan menerapkan BDR, yaitu: kesiapan infrastruktur, kemampuan guru

\footnotetext{
${ }^{23}$ Ahmad, "Peningkatan Kompetensi Pedagogik Guru Dalam Pembelajaran Jarak Jauh Melalui Pendampingan Sistem Daring, Luring Atau Kombinasi Pada Masa New Normal Covid-19," Jurnal Pedagogik: Jurnal Pendidikan Volume 7 Nomor 4 (Oktober 2020): 262.

${ }^{24}$ Ahmad, 262.

${ }^{25}$ Ahmad, 263.

${ }^{26}$ Suharsimi Arikunto and Lia Yuliana, Manajemen Pendidikan (Yogyakarta: Graha Cendekia, 2015), 280.

${ }^{27}$ Sarjono, "Penerapan Supervisi Akademik Pengawas Guna Meningkatkan Keterampilan Guru Dalam Melaksanakan Program Belajar Dari Rumah (BDR) Selama Masa Pandemi Covid-19 Di Dabin I Korwilcam Bidang Pendidikan Kecamatan Sumowono," Jurnal Wawasan Pengembangan Pendidikan Volume 8 Nomor 2 (2020): 57.
} 
memanfaatkan teknologi pembelajaran, perencanaan dan pembelajaran di masa pandemi, kesiapan siswa, peran kepala sekolah, guru dan orang tua dalam pembelajaran, dan kendala utama. Melalui supervisi yang berkelanjutan maka diharapkan guru dapat menyusun perangkat pembelajaran dengan baik dan dapat melaksanakan pembelajaran dengan baik pula. Hal ini sebagaimana hasil penelitian yang dilakukan oleh Cokorde Istri Mirah Kusuma Widiawati bahwa bimbingan berkelanjutan dalam upaya menerapkan mutu pembelajaran daring melalui supervisi akademik guru dapat meningkatkan motivasi guru dalam menyusun administrasi pembelajaran dengan lengkap sehingga menghasilkan pembelajaran yang lebih bermutu. ${ }^{28}$

Adanya supervisi akademik yang mampu meningkatkan keterampilan guru dalam melaksanakan pembelajaran daring juga dikuatkan oleh penelitian yang dilakukan oleh Sarjono. Dalam penelitiannya ditemukan bahwa penerapan supervisi akademik mampu meningkatkan keterampilan guru dalam melaksanakan program BDR di Dabin I Korwilcam Bidang Pendidikan Kecamatan Sumowono dengan rata-rata nilai keterampilan guru pada siklus I sebesar 72 (kategori cukup) yang kemudian meningkat menjadi 77.75 (kategori baik) pada siklus II. ${ }^{29}$ Upaya yang dilakukan dapat berupa pemberian bimbingan, pengarahan, pelatihan, pemberian motivasi, arahan maupun umpan balik. ${ }^{30}$

\section{Kesimpulan}

Pembelajaran daring yang dilaksanakan oleh hampir seluruh lembaga pendidikan di Indonesia selama masa pandemi ini perlu dipersiapkan dengan baik. Hal ini sebagai upaya untuk menjamin kualitas pendidikan, mengingat pembelajaran daring berlangsung lama. Kepala sekolah sebagai penanggung jawab lembaga pendidikan, perlu melakukan sejumlah terobosan untuk memastikan seluruh guru mampu melaksanakan pembelajaran daring dengan baik. Beberapa hal yang dapat dilakukan adalah dengan melaksanakan pelatihan pembelajaran daring, membentuk tim yang fokus mendampingi para guru dalam mempersiapkan pembelajaran daring serta melakukan supervisi akademik secara berkelanjutan. Dengan melalui berbagai upaya tersebut, diharapkan pembelajaran daring dapat dilaksanakan secara efektif.

\section{Daftar Pustaka}

Ahmad. "Peningkatan Kompetensi Pedagogik Guru Dalam Pembelajaran Jarak Jauh Melalui Pendampingan Sistem Daring, Luring Atau Kombinasi Pada Masa New Normal Covid-19." Jurnal Pedagogik: Jurnal Pendidikan Volume 7 Nomor 4 (Oktober 2020).

Almasri, M. Nazar. "Manajemen Sumber Daya Manusia: Implementasi Dalam Pendidikan Islam,." Kutubkhanan: Jurnal Penelitian Sosial Keagamaan Volume 19 Nomor 2 (July 2016).

\footnotetext{
${ }^{28}$ Cokorde Istri Mirah Kusuma Widiawati, "Upaya Peningkatan Mutu Pembelajaran Melalui Supervisi Akademik Guru Di SMA Negeri 7 Denpasar," Jurnal Widyadari Volume 22 Nomor 1 (n.d.): 124 .

${ }^{29}$ Sarjono, "Penerapan Supervisi Akademik Pengawas Guna Meningkatkan Keterampilan Guru Dalam Melaksanakan Program Belajar Dari Rumah (BDR) Selama Masa Pandemi Covid-19 Di Dabin I Korwilcam Bidang Pendidikan Kecamatan Sumowono," 6o.

${ }^{30}$ Sarjono, 56.
} 
Arikunto, Suharsimi, and Lia Yuliana. Manajemen Pendidikan. Yogyakarta: Graha Cendekia, 2015 .

Asmuni. "Asmuni, Problematika Pembelajaran Daring Di Masa Pandemi Covid-19 Dan Solusi Pemecahannya." Jurnal Paedagogy: Jurnal Penelitian Dan Pengembangan Pendidikan Volume 7 Nomor 4 (Oktober 2020).

Herliandry, Luh Devi, Nurhasanah, Maria Enjelina Suban, and Heru Kuswanto. "Pembelajaran Pada Masa Pandemi Covid-19." Jurnal Teknologi Pendidikan Volume 22 Nomor 1 (April 2020).

Kompri. Manajemen Pendidikan 2. Bandung: Alfabeta, 2014.

Kurniawati, Dhoni. "Manajemen Sumber Daya Manusia Dalam Perspektif Islam Dan Relevansinya Dengan Manajemen Modern." Ijtimaiyya: Jurnal Pengembangan Masyarakat Islam Volume 11 Nomor 1 (Pebruari 2018).

Lilawati, Agustien. "Peran Orang Tua Dalam Mendukung Kegiatan Pembelajaran Di Rumah Pada Masa Pandemi." Jurnal Obsesi: Jurnal Pendidikan Anak Usia Dini Volume 5 nomor (2021)

Lubis, Lutfi Erwin. "Lutfi Erwin Lubis, Efek Kompensasi Terhadap Motivasi Kerja Guru Pada Sekolah Widya Batam.” Jurnal Dimensi Volume 7 Nomor 3 (2018).

Machali dan Ara Hidayat, Imam. The Handbook Of Education Management. Jakarta: Prenadamedia Group, 2016.

Mulyasa. "Manajemen Berbasis Sekolah (Konsep, Strategi Dan Implementasi)." Bandung: PT Remaja Rosdakarya, 2014.

Nur, Anifa Alfia. “Anifa Alfia Nur, Meningkatkan Kompetensi Pedagogik Guru Di SD Yayasan Mutiara Gambut.” Jurnal Administrasi Pendidikan Volume 2 Nomor 1 (June 2014).

Samsudin, Sadili. Manajemen Sumber Daya Manusia. Bandung: Pustaka Setia, 2006.

Sari, Puput Maretha, Supardi A. Bakri, and Yuliansyah M. Diah. "Pengaruh Kompensasi Terhadap Disiplin Kerja Pegawai Pada Lembaga Penjaminan Mutu Pendidikan Sumatera Selatan." Jembatan: Jurnal Ilmiah Manajemen Bisnis Dan Terapan Volume 12 Nomor 2 (Oktober 2015).

Sarjono. "Penerapan Supervisi Akademik Pengawas Guna Meningkatkan Keterampilan Guru Dalam Melaksanakan Program Belajar Dari Rumah (BDR) Selama Masa Pandemi Covid-19 Di Dabin I Korwilcam Bidang Pendidikan Kecamatan Sumowono." Jurnal Wawasan Pengembangan Pendidikan Volume 8 Nomor 2 (2020).

Sholihah, Hidayatus. "Implementasi Manajemen SDM Di MAN Yogyakarta III.” Al Fikr: Jurnal Studi Dan Penelitian Pendidikan Islam Volume 1 Nomor 1 (February 2018).

Tafsir, Ahmad. Ilmu Pendidikan Islami. Bandung: PT Remaja Rosdakarya, 2012.

Widiawati, Cokorde Istri Mirah Kusuma. "Upaya Peningkatan Mutu Pembelajaran Melalui 
Supervisi Akademik Guru Di SMA Negeri 7 Denpasar.” Jurnal Widyadari Volume 22 Nomor 1 (n.d.).

Yuniarsih, Tjuju, and Suwatni. "Manajemen Sumber Daya Manusia (Teori, Aplikasi Dan Isu Penelitian." Bandung: Alfabeta, 2013.

Yusutria. "Profesionalisme Guru Dalam Meningkatkan Kualitas Sumber Daya Manusia." Jurnal Curricula Volume 2 Nomor 1 (2017). 